\title{
Distribution of amine oxidases and amine dehydrogenases in bacteria grown on primary amines and characterization of the amine oxidase from Klebsiella oxytoca
}

\author{
Ayse Hacisalihoglu, Jaap A. Jongejan and Johannis A. Duine \\ Author for correspondence: J. A. Duine. Tel: +31 15 2785051. Fax: +31 152782355. \\ e-mail: J. A. Duine@STM.TUDelft.NL
}

Department of Microbiology and Enzymology, Delft University of Technology, Julianalaan $67,2628 \mathrm{BC}$ Delft, The Netherlands

\begin{abstract}
The bacteria Klebsiella oxytoca LMD 72.65 (ATCC 8724), Arthrobacter P1 LMD 81.60 (NCIB 11625), Paracoccus versutus LMD 80.62 (ATCC 25364), Escherichia coli W LMD 50.28 (ATCC 9637), E. coli K12 LMD 93.68, Pseudomonas aeruginosa PAO1 LMD 89.1 (ATCC 17933) and Pseudomonas putida LMD 68.20 (ATCC 12633) utilized primary amines as a carbon and energy source, although the range of amines accepted varied from organism to organism. The Gram-negative bacteria $K$. oxytoca and $E$. coli as well as the Gram-positive methylotroph Arthrobacter P1 used an oxidase whereas the pseudomonads and the Gramnegative methylotroph Paracoccus versutus used a dehydrogenase for amine oxidation. $K$. oxytoca utilized several primary amines but showed a preference for those containing a phenyl group moiety. Only a single oxidase was used for oxidation of the amines. After purification, the following characteristics of the enzyme indicated that it belonged to the group of copper-quinoprotein amine oxidases (EC 1.4.3.6): the molecular mass (172000 Da) of the homodimeric protein; the UV/visible and EPR spectra of isolated and pnitrophenylhydrazine-inhibited enzyme; the presence and the content of copper and topaquinone (TPQ). The amine oxidase appeared to be soluble and localized in the periplasm, but catalase and NAD-dependent aromatic aldehyde dehydrogenase, enzymes catalysing the conversion of its reaction products, were found in the cytoplasm. From the amino acid sequence of the $\mathrm{N}$-terminal part as well as that of a purified peptide, it appears that $K$. oxytoca produces a copper-quinoprotein oxidase which is very similar to that found in other Enterobacteriaceae.
\end{abstract}

Keywords: amine oxidases, amine dehydrogenases, copper-quinoprotein amine oxidase, topaquinone, Klebsiella oxytoca

\section{INTRODUCTION}

Many micro-organisms convert primary amines via an oxidation step into products which can be utilized either as a carbon and/or energy source, as a nitrogen source or as both (Yamada et al., 1965; Levering et al., 1981):

$\mathrm{R}-\mathrm{CH}_{2} \mathrm{NH}_{2}+\mathrm{H}_{2} \mathrm{O} \rightarrow \mathrm{RCHO}+2[\mathrm{H}]+\mathrm{NH}_{3}$

Abbreviations: IEF, isoelectric focusing; $p N P H$, para-nitrophenylhydrazine; PEA, phenylethylamine; TPQ, topaquinone; TTQ, tryptophyl tryptophanquinone.

The EMBL accession number for the sequence reported in this paper is P80695.
Various enzymes with different cofactors and mechanisms of action can bring about this oxidation. These include quinoprotein amine dehydrogenase (EC 1.4.99.3), which contains TTQ [tryptophyl tryptophanquinone, the trivial name or 4-(2'tryptophyl)tryptophan-6,7-dione]; a number of dehydrogenases with unidentified cofactors; flavoprotein amine oxidase (EC 1.4.3.4); and quinoprotein amine oxidase (EC 1.4.3.6), which contains copper and TPQ (topaquinone, the trivial name for 6-hydroxyphenylalanine-3,4-dione). In an attempt to determine which enzymes are used by various bacteria, we have investigated the bacteria's capacity to utilize a number of simple aliphatic and phenyl-group-containing pri- 
mary amines as a carbon and energy source, and have identified the type of oxidoreductase involved.

Among the bacteria tested, Klebsiella oxytoca was able to utilize 2-phenylethylamine (PEA), and preliminary characterization of the oxidase involved revealed properties reminiscent of a soluble, copper-TPQ-containing amine oxidase. In these respects, the enzyme seemed to be different from that induced during growth on tyramine of a closely related organism, Klebsiella aerogenes ( $K$. pneumoniae), originally reported to be a membrane-integrated monoamine oxidase (Okamura et al., 1976). This name is usually reserved for flavoprotein amine oxidases (EC 1.4.3.4), such an enzyme, for example, occurring in tyramine-grown Sarcina lutea (Kumagai et al., 1969). Later on (Yamashita et al., 1993), a gene was cloned from this bacterium, the expression of which yielded a soluble amine oxidase. Since this discrepancy has not been resolved and the nature of the enzymes has not been established (the authors did not discuss the possibility that the soluble enzyme might be of the copper-quinoprotein type), we have attempted to characterize the $K$. oxytoca amino oxidase and to investigate whether growth on different amines induces production of different amine oxidoreductases in this organism.

\section{METHODS}

Materials. Mono Q HR $5 / 5$ and $10 / 10$, Phenyl-Superose $5 / 5$ and Superose $12 \mathrm{HR}$ 10/30 chromatography columns, HPLC reversed phase column Superpac Pep-S $5 \mu \mathrm{m} \mathrm{C}_{2} / \mathrm{C}_{18}$, Phast system electrophoresis apparatus and kits with standard proteins and isoelectric focusing equipment, and PD 10 desalting columns were from Pharmacia; trifluoracetic acid, reversed phase $5 \mu \mathrm{m} \mathrm{C}_{18}$ and $5 \mu \mathrm{m} \mathrm{C}_{8}$ HPLC columns, and Pronase E were from Merck; Sep-Pak $\mathrm{C}_{18}$ cartridges were from Waters/Millipore; $p$-nitrophenylhydrazine. $\mathrm{HCl}$ ( $p$ NPH) was from Fluka.

Cultivation of bacteria. Klebsiella oxytoca LMD 72.65 (ATCC 8724), Arthrobacter P1 LMD 81.60 (NCIB 11625), Paracoccus versutus LMD 80.62 (ATCC 25364), Escherichia coli W LMD 50.28 (ATCC 9637), E. coli K12 LMD 93.68, Pseudomonas aeruginosa PAO1 LMD 89.1 (ATCC 17933) and Pseudomonas putida LMD 68.20 (ATCC 12633) were obtained from the Laboratory of Microbiology Delft culture collection. The ability to utilize amines was studied by transferring the bacteria to a mineral medium supplemented with Luria broth $\left(0.25 \mathrm{~g} \mathrm{l}^{-1}\right)$, thiamin $\left(50 \mathrm{mg} \mathrm{l}^{-1}\right)$ and the amine $(5 \mathrm{mM})$. The mineral medium, brought to $\mathrm{pH} 7.0$, contained $4.5 \mathrm{~g} \mathrm{KH}_{2} \mathrm{PO}_{4}$, $11.7 \mathrm{~g} \mathrm{~K}_{2} \mathrm{HPO}_{4}$ and $3 \mathrm{~g}\left(\mathrm{NH}_{4}\right)_{2} \mathrm{SO}_{4}$ per litre. The trace element solution (Vishniac \& Santer, 1957), and the amines (as their $\mathrm{HCl}$ salts) were filter-sterilized and added separately to the heat-sterilized mineral medium. The trace element solution for Paracoccus versutus contained a fivefold higher concentration of copper salt. Thiamin was not incorporated in the media for the Pseudomonas aeruginosa and P. putida strains. The inoculated media $(500 \mathrm{ml})$ were shaken in Erlenmeyer flasks (2l) at 200 r.p.m. at $30^{\circ} \mathrm{C}$. The ability to utilize the amine was judged from the turbidity of the medium as compared to that in which the amine was lacking. Experiments were discontinued after $7 \mathrm{~d}$. To determine the type of amine oxidoreductase involved, cells were harvested in the midexponential growth phase $\left(\mathrm{OD}_{600}\right.$ approx. $\left.0 \cdot 6-0 \cdot 8\right)$. To provide cells for isolating the amine oxidase and to perform localization studies of the enzymes, $K$. oxytoca was grown aerobically in a 1001 fermenter at $30^{\circ} \mathrm{C}$ in the mineral medium supplemented with $5 \mathrm{mM}$ PEA. The cells were harvested in the mid-exponential growth phase.

Localization of enzyme activities. The periplasmic fraction of $K$. oxytoca was prepared according to Rassoulzadegan et al. (1982) and Cooper et al. (1992).

Enzyme assays. The specific activities of $K$. oxytoca amine oxidase were determined spectrophotometrically using PEA as a substrate and measuring formation of phenylacetaldehyde in the form of its semicarbazone by including semicarbazide in the assay mixture. Although semicarbazide is a weak inhibitor of amine oxidase, inhibition does not occur in the presence of PEA (checked with the polarographic assay, see below), presumably because the substrate reacts more effectively with TPQ than the inhibitor. The assay mixture $(1 \mathrm{ml})$ consisted of $75 \mathrm{mM}$ sodium/potassium phosphate buffer, $\mathrm{pH} 6 \cdot 1,0.5 \mathrm{mM}$ PEA-HCl and $1 \mathrm{mM}$ semicarbazide. $\mathrm{HCl}$. The reaction was started by adding enzyme and the increase in $A_{230}$ was monitored against a blank containing all components except the enzyme. The molar absorption coefficient for phenylacetaldehyde semicarbazone used was $1.6 \times 10^{4} \mathrm{M}^{-1} \mathrm{~cm}^{-1}$ (Parrot et al., 1987). All assays were carried out at $30^{\circ} \mathrm{C}$. One unit of activity (U) is the amount of enzyme catalysing the formation of $1 \mu \mathrm{mol}$ semicarbazone $\mathrm{min}^{-1}$.

Determinations of amine oxidase activity in general and of the substrate specificity of $K$. oxytoca amine oxidase were carried out polarographically. Initial rates of oxygen uptake were measured with a Clark oxygen electrode. The assay mixture ( $3 \mathrm{ml}$ ) consisted of $0 \cdot 1 \mathrm{M}$ sodium/potassium phosphate buffer, $\mathrm{pH} 7 \cdot 0$, containing $1 \mathrm{mM}$ amine.

Amine dehydrogenase activity was determined spectrophotometrically at $600 \mathrm{~nm}$ by phenazine methosulphate (PMS)-mediated reduction of 2,6-dichlorophenolindophenol (DCPIP) or by direct reduction of DCPIP (Eady \& Large, 1968).

Catalase activity was determined by monitoring the decomposition of $\mathrm{H}_{2} \mathrm{O}_{2}$ spectrophotometrically. The reaction mixture $(1 \mathrm{ml})$ consisted of $80 \mathrm{mM}$ sodium/potassium phosphate buffer, $\mathrm{pH} 7 \cdot 0$, containing $15 \mathrm{mM} \mathrm{H}_{2} \mathrm{O}_{2}$. A molar absorption coefficient for $\mathrm{H}_{2} \mathrm{O}_{2}$ of $40 \mathrm{M}^{-1} \mathrm{~cm}^{-1}$ at $240 \mathrm{~nm}$ was used.

Phenylacetaldehyde dehydrogenase activity was assayed by measuring the formation of NADH spectrophotometrically. The reaction mixture $(1 \mathrm{ml})$ consisted of $93 \mathrm{mM}$ sodium/ potassium phosphate buffer, $\mathrm{pH} 8.0$, containing $0.75 \mathrm{mM}$ $\mathrm{NAD}^{+}$, and $10 \mathrm{mM}$ phenylacetaldehyde. A molar absorption coefficient for NADH of $6220 \mathrm{M}^{-1} \mathrm{~cm}^{-1}$ at $340 \mathrm{~nm}$ was used.

Malate dehydrogenase activity was determined spectrophotometrically by measuring the initial rate of its reverse reaction (Kitto, 1969).

Purification of $\boldsymbol{K}$. oxytoca amine oxidase. Crude extract was prepared according to Haywood \& Large (1981). Ammonium sulphate was added to the crude extract $(26 \mathrm{ml}$, kept in an icewater bath) while stirring. The precipitate formed between $60 \%$ and $90 \%$ saturation was collected by centrifugation ( $30 \mathrm{~min}$ at $20000 \mathrm{~g}, 4^{\circ} \mathrm{C}$ ). The pellet was dissolved in $50 \mathrm{ml}$ $20 \mathrm{mM}$ Tris/ $\mathrm{HCl}$ buffer, $\mathrm{pH} 7 \cdot 0$, and the solution was dialysed against the same buffer at $4^{\circ} \mathrm{C}$. All subsequent steps were performed at room temperature. The dialysate was applied to a Mono Q 10/10 anion-exchange column equilibrated with the same buffer and eluted with a $160 \mathrm{ml}$ linear gradient of $0-0.5 \mathrm{M} \mathrm{NaCl}$ in the buffer at a flow rate of $2 \mathrm{ml} \mathrm{min}^{-1}$. The enzyme eluted at about $0.1 \mathrm{M} \mathrm{NaCl}$. Solid ammonium sulphate was added to the pooled active fractions to a conc- 
entration of $1.7 \mathrm{M}$ and the solution was applied to a PhenylSuperose 5/5 hydrophobic interaction chromatography column equilibrated with $50 \mathrm{mM}$ sodium phosphate buffer, pH 7.0, containing $1.7 \mathrm{M}$ ammonium sulphate. A $15 \mathrm{ml}$ linear gradient of $1.7-0 \mathrm{M}$ ammonium sulphate was applied at a flow rate of $0.5 \mathrm{ml} \mathrm{min}^{-1}$. Amine oxidase activity eluted at about $0.34 \mathrm{M}$ ammonium sulphate. Active fractions were pooled and stored at $-80^{\circ} \mathrm{C}$. Ammonium sulphate was removed by gel filtration chromatography on a PD 10 column when required.

Isolation of the cofactor-p-nitrophenylhydrazine product. The purified amine oxidase (149 nmol) in $50 \mathrm{mM}$ sodium phosphate buffer, $\mathrm{pH} 7 \cdot 0$, was incubated with $p \mathrm{NPH}$ $(450 \mathrm{nmol})$ at room temperature for $30 \mathrm{~min}$. Excess $p \mathrm{NPH}$ was removed on a PD 10 column which was equilibrated with $50 \mathrm{mM}$ sodium phosphate buffer, $\mathrm{pH} 7 \cdot 0$. The $p \mathrm{NPH}$ derivatized amine oxidase was digested with Pronase E $\left(16 \mathrm{mg}\right.$ ) for $24 \mathrm{~h}$ at $37^{\circ} \mathrm{C}$. The cofactor- $p$-nitrophenylhydrazine product was isolated according to Steinebach $e t$ al. (1995).

Polyacrylamide gel electrophoresis and isoelectric focusing. Polyacrylamide gel electrophoresis (PAGE) and isoelectric focusing (IEF) were performed on commercially available gels (8-25\% gradient gel for native PAGE; $12.5 \%$ homogeneous gels for SDS-PAGE; and IEF 5-8 gels for IEF) using the Pharmacia Phast system according to the instructions provided by the manufacturer. The high molecular kit for native PAGE and the low molecular kit for SDS-PAGE were used for calibration.

Isolation of the CNBr cleavage fragment. Purified enzyme $(0.2 \mathrm{ml} ; 0.24 \mathrm{mg}$ protein) was added to $1 \mathrm{ml} 70 \%$ formic acid containing $0.17 \mathrm{~g} \mathrm{CNBr}$ and incubated for $24 \mathrm{~h}$ at room temperature in the dark. Formic acid was evaporated in a vacuum desiccator over $\mathrm{NaOH}$. The $S-S$ bridges in the peptides were split by dissolving the residue in $0.1 \mathrm{M}$ Tris $/ \mathrm{HCl}$ buffer, $\mathrm{pH} 8.5$, containing $6 \mathrm{M}$ guanidine. $\mathrm{HCl}$, and $0 \cdot 1 \mathrm{M}$ dithiothreitol. The solution was centrifuged and applied to a reversed phase column (Superpac Pep-S $5 \mu \mathrm{m} \quad \mathrm{C}_{2} / \mathrm{C}_{18}$ ) equilibrated with $0 \cdot 2 \%$ trifluoroacetic acid and the peptides were eluted with a 90 min linear gradient from 0 to $90 \%$ acetonitrile in $0.2 \%$ trifluoroacetic acid at a flow rate of $0.5 \mathrm{ml}$ $\mathrm{min}^{-1}$. The purity of the collected fractions was checked by SDS-PAGE using a $20 \%$ gel. A fraction (retention time $48 \mathrm{~min}$ ) containing a peptide which showed a single band on the SDSPAGE was chosen for amino acid sequencing. The acetonitrile was removed under vacuum.

Analytical methods. Protein concentrations were determined according to Bradford (1976) using desalted bovine serum albumin as a standard. The specific absorption coefficient of the enzyme at $280 \mathrm{~nm}$ was determined by monitoring the eluting peak with a photodiode-array detector at 280 and $205 \mathrm{~nm}$ (van Iersel et al., 1985). Copper was determined by both flame atomic absorption spectroscopy and a chemical assay (Felsenfeld, 1960). ${ }^{1} \mathrm{H}-\mathrm{NMR}$ spectroscopy was performed on a Bruker $600 \mathrm{MHZ}$ spectrometer and EPR spectroscopy on a Varian E-9 spectrometer. Amino acid sequencing was performed by automatic Edman degradation.

\section{RESULTS AND DISCUSSION}

\section{Utilization of amines and type of oxidoreductase involved in their conversion}

All of the bacteria investigated were able to utilize at least one of the amines tested (benzylamine, phenylethylamine, tyramine, methylamine, ethylamine and butylamine) as a carbon and energy source. However, there was substantial variation in the broadness of the range that could be utilized (only one, tyramine, for Pseudomonas aeruginosa; all except benzylamine for Arthrobacter P1) and type of amine that could be utilized (aromatic amines for E. coli, aliphatic amines for Paracoccus versutus). There was also variation in the type of amine oxidoreductase activity involved in the conversion, with extracts of the Enterobacteriaceae and the Gram-positive methylotrophs Arthrobacter P1 and Amycolatopsis methanolica (not shown) exhibiting oxidase activity and those of the pseudomonads and the Gram-negative methylotroph $P$. versutus exhibiting dehydrogenase activity. Given that the oxidase activity was found in extracts after ultracentrifugation and that $\mathrm{KCN}$ was not an inhibitor, it seems most likely that the activity results from a real oxidase and not a dehydrogenase transferring the reducing equivalents to the respiratory chain. The amine dehydrogenase activity of $P$. aeruginosa was found to be attached to membrane particles (obtained by ultracentrifugation of the extract at $50000 \mathrm{~g}$ for $2 \mathrm{~h}$ ), in agreement with others (Cuskey $e t$ al., 1987). Either an oxidase or a dehydrogenase was involved in the conversion of all amines utilized by a particular bacterium. Apparently it is the species rather than the substrate that determines which type of oxidoreductase is used for the conversion. In this respect, it is interesting to note that amine dehydrogenase activity was found only in Gram-negative bacteria. However, amine dehydrogenases do not have an exclusive role in this type of bacteria since Enterobacteriaceae possess an amine oxidase, implying that amine utilization by the latter requires an aerobic environment. Amine oxidase activities induced in PEAand tyramine-grown $K$. oxytoca derive from the same enzyme, as judged from the identical behaviour of the purified enzymes on SDS-PAGE and the identical substrate specificities (not shown), the latter mimicking the growth pattern of the organism (good growth on $\mathrm{PEA}$ and tyramine, poor growth on butylamine, no growth on methylamine, ethylamine or benzylamine).

\section{Characteristics of purified $K$. oxytoca amine oxidase}

Amine oxidase purified from PEA-grown $K$. oxytoca (Table 1) migrated as a single protein band when subjected to SDS-PAGE. The specific activity of the pure enzyme with $0.5 \mathrm{mM}$ tyramine or PEA as substrate was $5.6 \mathrm{U}$ (mg protein $)^{-1}$. High activity was observed with tyramine $(100 \%)$, PEA $(100 \%)$ and tryptamine $(100 \%)$, moderate activity with butylamine $(65 \%)$ but no activity with benzylamine, methylamine, cadaverine or putrescine. Very low apparent $K_{\mathrm{m}}$ values (lower than $5 \mu \mathrm{M}$ ) were observed for the aromatic amines under air saturation. Apparently, the enzyme has a preference for primary amines (with more than one carbon atom) containing a phenyl moiety.

The absorption spectrum of the purified amine oxidase (Fig. 1) showed the characteristic features of copperquinoprotein amine oxidases with a $470 \mathrm{~nm}$ absorption 
Table 1. Purification of amine oxidase from $K$. oxytoca

\begin{tabular}{|lccccc|}
\hline Purification step & $\begin{array}{c}\text { Total } \\
\text { protein } \\
(\mathbf{m g})\end{array}$ & $\begin{array}{c}\text { Total } \\
\text { activity } \\
(\mathbf{U})\end{array}$ & $\begin{array}{c}\text { Specific } \\
\text { activity } \\
\left(\mathbf{U ~ m g}^{-1}\right)\end{array}$ & $\begin{array}{c}\text { Recovery } \\
\text { (\%) }\end{array}$ & $\begin{array}{c}\text { Purification } \\
\text { (-fold) }\end{array}$ \\
\hline Crude extract & 343 & 56 & $0 \cdot 16$ & 100 & 1 \\
$\left(\mathrm{NH}_{4}\right)_{\mathbf{2}} \mathrm{SO}_{4}$ precipitation & 247 & 50 & $0 \cdot 2$ & 89 & 68 \\
Anion-exchange (Mono Q) chromatography & $9 \cdot 3$ & 38 & $4 \cdot 1$ & 5.2 & 35 \\
Hydrophobic interaction chromatography & $5 \cdot 0$ & 31 & $5 \cdot 6$ & 54 \\
\hline
\end{tabular}

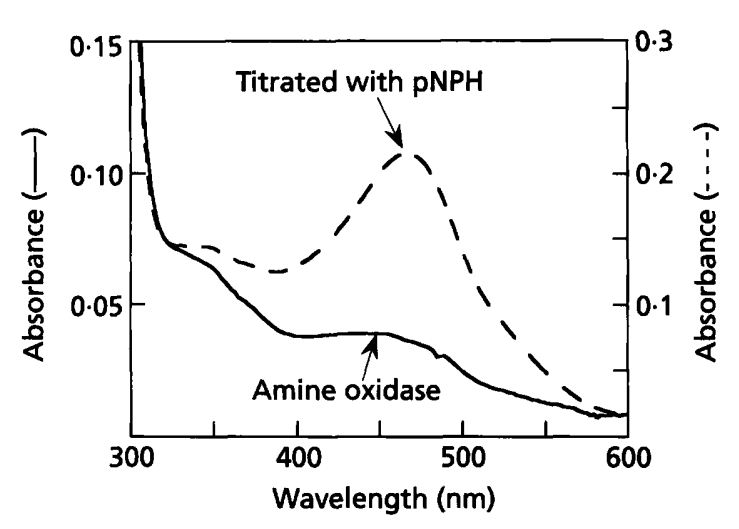

Fig. 1. Absorption spectra of untreated and pNPH-treated $K$. oxytoca amine oxidase. Absorption spectra of the enzyme $\left(3.5 \mathrm{nmol}, 0.56 \mathrm{mg}\right.$ protein $\mathrm{ml}^{-1}$ ) were measured in $50 \mathrm{mM}$ potassium phosphate buffer, $\mathrm{pH} \mathrm{7.0.}-$, Untreated enzyme; ----, enzyme derivatized with $3.5 \mathrm{nmol}$ pNPH.

band (Steinebach et al., 1996). Isoelectric focusing revealed a single band which corresponded to an isoelectric point of $5 \cdot 7$, indicating that the amine oxidase is an acidic protein. The molecular masses of the native enzyme and its subunit, as determined with PAGE and SDS-PAGE, were $172 \mathrm{kDa}$ and $86 \mathrm{kDa}$, respectively, indicating that the enzyme is a dimeric protein. One enzyme molecule contained 2.0 copper atoms according to chemical assay and 1.7 according to atomic absorption spectrophotometry. The purified enzyme also showed the characteristic EPR spectrum of copperquinoprotein amine oxidases (not shown). It is concluded, therefore, that the enzyme contains two $\mathrm{Cu}^{2+}$ ions per molecule, a value typical for quinoprotein amine oxidases (Knowles \& Dooley, 1994). The amine oxidase was sensitive to carbonyl group reagents such as phenylhydrazine and semicarbazide. Semicarbazide at a concentration of $10 \mu \mathrm{M}$ gave about $30 \%$ inhibition, whereas $55 \%$ inhibition was observed with $100 \mathrm{nM}$ phenylhydrazine ( $2 \mathrm{~min}$ incubation at room temperature prior to the assay). $p$ NPH reacted rapidly with the amine oxidase, as judged from the inhibition and concomitant spectral changes induced (Fig. 1). Since the ${ }^{1} \mathrm{H}-\mathrm{NMR}$ spectrum of the isolated cofactor- $p$ NPH product (Fig. 2) is virtually identical to that for the cofactor- $p \mathrm{NPH}$ peptide from bovine serum amine oxidase (Janes et al., 1990) and the cofactor- $p$ NPH product isolated from $E$. coli amine oxidase or pig kidney diamine oxidase (Steinebach et al., 1995), we conclude that TPQ is present in this enzyme.

These characteristics indicate that $K$. oxytoca utilizes a copper-quinoprotein amine oxidase for growth on PEA or tyramine. In this respect, the organism is comparable to other Enterobacteriaceae like E. coli (Cooper et al., 1992; Steinebach et al., 1995) and most probably (see below) K. aerogenes (K. pneumoniae) (Yamashita et al., 1993). Surprisingly, other Gram-negative bacteria convert these substrates via quite different types of oxidoreductases: Alcaligenes faecalis with a periplasmic, TTQ-containing amine dehydrogenase (Govindaraj et al., 1994); Pseudomonas aeruginosa with a membranebound, uncharacterized amine dehydrogenase (Cuskey et al., 1987); Pseudomonas putida with a soluble haemcontaining amine dehydrogenase (Durham \& Perry, 1978); Sarcina lutea with a flavoprotein amine oxidase (Kumagai et al., 1969). At present, the reason for this diversity of enzymes catalysing the same reaction, and having similar substrate specificity, is unknown. However, it is certainly not related to the type of substrates which have to be converted since enzymes involved in aliphatic primary amine oxidation are similarly diverse. Neither is it due to a special type of organism, at least with respect to copper-TPQ-containing amine oxidase, since this type of amine oxidase occurs not only in Gram-negative, Gram-positive, and methylotrophic bacteria but also in eukaryotes such as yeasts (Large $\&$ Haywood, 1990) and fungi (Yamada \& Adachi, 1971).

As shown in Table $2,83 \%$ of the amine oxidase activity of $K$. oxytoca was detected in the periplasmid fraction and only $17 \%$ in the cytoplasmic/membrane fraction. In contrast, catalase and phenylacetaldehyde dehydrogenase activity were nearly absent from the periplasmic fraction. As shown by the distribution values of the marker enzyme, cytoplasmic malate dehydrogenase, adequate preparation of the cellular fractions was achieved. Thus, the distribution and the properties show that the $K$. oxytoca amine oxidase is, like the E. coli enzyme (Cooper et al., 1992), not a membraneintegrated enzyme but a soluble periplasmic enzyme. Whether the location, periplasmic in Gram-negatives and probably cytoplasmic or membrane-bound in 


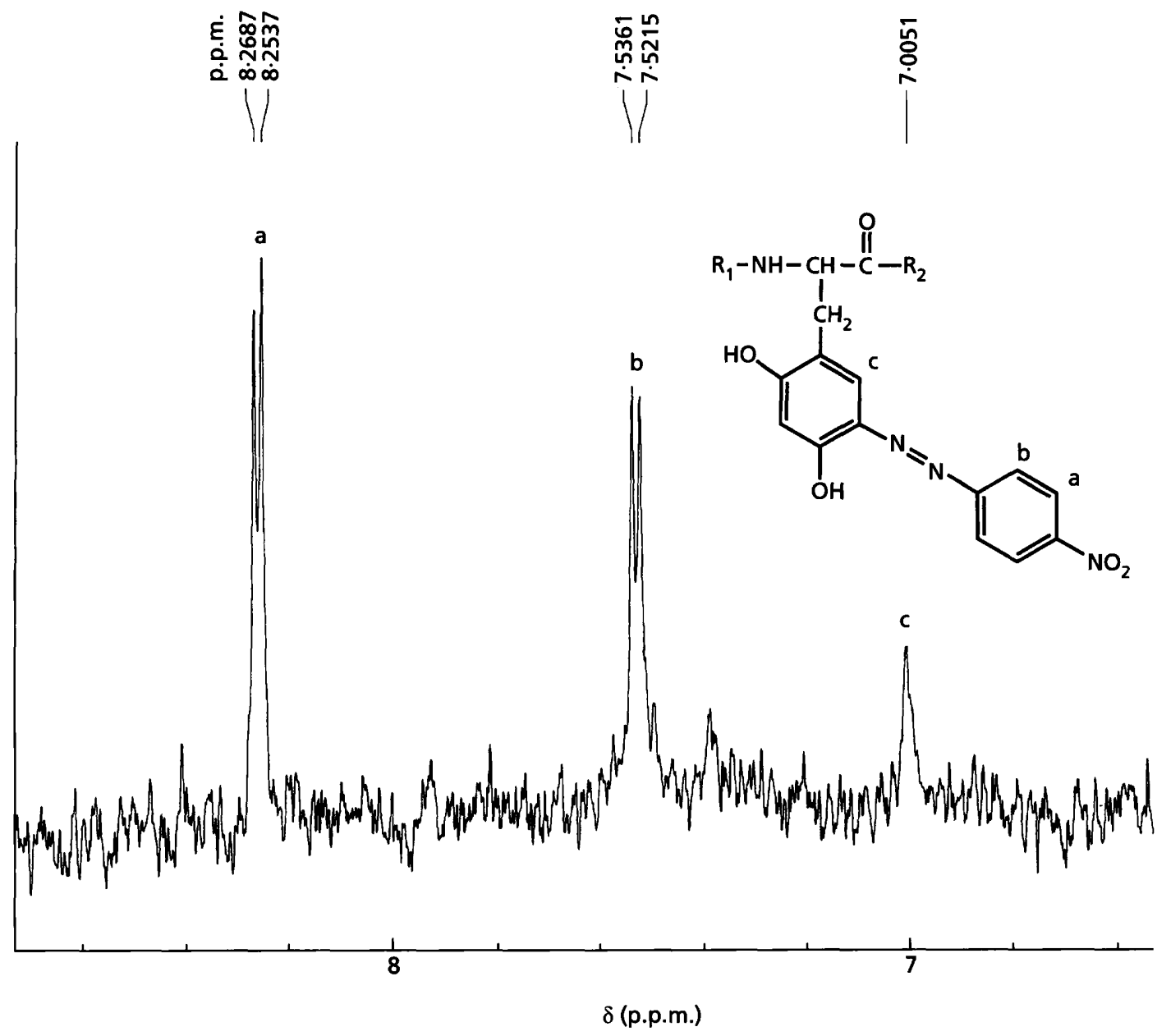

Fig. 2. ${ }^{1} \mathrm{H}$-NMR spectrum of cofactor-p-nitrophenylhydrazine product isolated from $K$. oxytoca amine oxidase. The spectrum of the purified cofactor adduct was taken in $\mathrm{D}_{2} \mathrm{O}, \mathrm{pH} 7 \cdot 5$. The deduced structure of the cofactor (TPQ) is shown in an inset.

Table 2. Distribution of enzyme activity in cellular fractions of $K$. oxytoca

\begin{tabular}{|lcc|}
\hline Enzyme & \multicolumn{1}{c|}{$\begin{array}{c}\text { Activity (percentage of } \\
\text { activity of crude extract) in: }\end{array}$} \\
\cline { 2 - 3 } & $\begin{array}{c}\text { Cytoplasm/ } \\
\text { membrane }\end{array}$ & Periplasm \\
\hline Amine oxidase & 17 & 83 \\
Catalase & 99 & 1 \\
$\begin{array}{l}\text { Phenylacetaldehyde } \\
\text { dehydrogenase }\end{array}$ & 85 & 15 \\
Malate dehydrogenase & 93 & 7 \\
\hline
\end{tabular}

Gram-positives (Levering et al., 1981) and peroxisomal in yeasts (Bruinenberg et al., 1989), is related to structural differences of the enzymes (see below) is presently unknown. Although the products of the reaction, $\mathrm{H}_{2} \mathrm{O}_{2}$ and aldehyde, are very toxic, apparently $K$. oxytoca is able to cope with them by transforming these compounds into less toxic products by the cytoplasmic catalase and NAD-dependent phenylacetaldehyde dehydrogenase activities. The latter has been purified and appears to be an aromatic aldehyde dehydrogenase (D. M. A. M. Luykx, M. Chettou, J. A. E. Benen, P. W. Postma, S. de Vries \& J. A. Duine, unpublished observations).

\section{Comparison with other copper-quinoprotein amine oxidases}

The alignment of the sequence of the $\mathrm{N}$-terminal region and the purified peptide from $K$. oxytoca amine oxidase with similar stretches from other copper-quinoprotein amine oxidases shows high similarity with those of $E$. coli and $K$. aerogenes (K. pneumoniae) but much less with those of the Gram-positive bacteria Arthrobacter P1, A. globiformis and the yeast Hansenula polymorpha 
Enzyme from:

Amino acid sequences

N-terminal

Peptide

K.oxytoca

K. aerogenes

E. coli

Arthrobacter P1

A. globiformis

H. polymorpha

Bovine serum

Pea seedling

Lentil seedling
HGGEAHMVPMDKTLQDFGAD

HGSEAHMVPLDKTLKEFGAD

HGGEAHMVPMDKTLQDFGAD
DKOLWVTRYHPTERFPEGKYPNRSIHDTGLGQYAKD

${ }^{665}$ DKQLWVTRYHDTERY PEGKY PNRSAHDTGLGQYAKD

${ }^{665}$ DKQLWVTRYHPGERF'PEGKY PNRSTHDTGLGQYSKD

539 RNNLWVTAYDRTERFAAGEYPNQATGGADDGLHIWT

\$41 TKDLFVTRYADDERYPTGDFVNQHSGGAGLPSY IAQ

370 SHSVNVVPYKDNRLYPSGDHVPQWSGDGVRGMREW I

${ }^{628}$ RYQLAITQRKETEPSSSSVFNQNDPWTPTVDFSDFI

549 NYNVWVTAYNRTEKWAGGLYVDHSRGDDTLAVWTKQ

549 NYNVWVTPYNRTEKWAGGLYVDHSRGDDTLAVWTKK

Fig. 3. Alignment of the amino acid sequence of the purified peptide and $\mathrm{N}$-terminal part of $K$. oxytoca amine oxidase with similar stretches from other amine oxidases. Amino acids identical with $K$. oxytoca amine oxidase are indicated in bold. Comparisons were made with published sequences for: overexpressed monoamine oxidase from $K$. aerogenes $(K$. pneumoniae) (Yamashita et al., 1993); tyramine oxidase from E. coli W3110 (Azakami et al., 1994); methylamine oxidase from Arthrobacter P1 (Zhang et al., 1993); PEA oxidase from A. globiformis (Tanizawa et al., 1994); methylamine oxidase from the yeast $H$. polymorpha (Bruinenberg et al., 1989); bovine serum amine oxidase (Mu et al., 1994); pea and lentil seedling amine oxidases (Tipping \& McPherson, 1995).

(Fig. 3). With respect to the $\mathrm{N}$-terminal region, this is not surprising since a stretch of about 100 amino acids is lacking in the $\mathrm{N}$-terminal region in the amine oxidases of Gram-positive bacteria (Roh et al., 1994).

Okamura et al. (1976) and Sugino et al. (1991) reported an amine oxidase in $K$. aerogenes ( $K$. pneumoniae) which was a membrane-integrated, hydrophobic enzyme, but they were unable to isolate it. However, overexpression of the cloned gene in the same strain yielded a soluble enzyme which could be purified (Yamashita et al., 1993); this observation was supported by the fact that the sequence of the structural gene did not predict a hydrophobic protein (Sugino et al., 1992). The discrepancy could be explained by assuming that this $K$. aerogenes strain can produce two different amine oxidases, a membrane-integrated one and a soluble one, also supported by the observation that the former did not oxidize PEA (Okamura et al., 1976) whereas the latter did (Yamashita et al., 1993). From the sequence comparison (Fig. 3), it appears that the soluble one is very similar to the enzyme described here. On the other hand, the specific activity and the copper content of the $K$. aerogenes enzyme were much lower (Yamashita et al., 1993) than those observed here for the K. oxytoca enzyme. However, since the copper catalyses the conversion of the precursor tyrosyl residue into TPQ (Matsuzaki et al., 1994, 1995) and addition of copper to the recombinant enzyme increased the activity by $83 \%$ (Yamashita et al., 1993), the lower values may be partly due to suboptimal processing of the pro-enzyme in the overexpression system of the host. Therefore, all the available evidence indicates now that amine oxidation by Enterobacteriaceae, including Klebsiella species, can be catalysed by a copper-TPQ-containing amine oxidase. On the other hand, the ability of these organisms to produce another amine oxidase cannot be discounted. Apart from the indications for the $K$. aerogenes strain, it has been found that amine oxidases with different substrate specificity are produced by the same organism grown on different amines; this is the case for the mould Aspergillus niger (Frebort et al., 1996), the yeast Hansenula polymorpha (Bruinenberg et al., 1989; Mu et al., 1992), and the Gram-positive bacterium Arthrobacter globiformis (Tanizawa et al., 1994; Shimizu et al., 1994). Although the results presented here for $K$. oxytoca indicate that a single amine oxidase is involved in the conversion of all amines utilized, it remains possible that another enzyme could be induced under different growth conditions. In this connection, it would be interesting to study the type of amine oxidoreductase induced when the amines serve only as a nitrogen source.

\section{ACKNOWLEDGEMENTS}

The authors are grateful to Dr Simon de Vries in our laboratory for performing EPR spectroscopy, to Dr Sybren S. Wijmenga, SON National HF-NMR Facility, Nijmegen, for performing ${ }^{1} \mathrm{H}-\mathrm{NMR}$ spectroscopy, and to $\mathrm{Dr}$ Friedrich Lottspeich, Max-Planck Institut für Biochemie, Munich, for sequencing the $\mathrm{N}$-terminal amino acids.

\section{REFERENCES}

Azakami, H., Yamashita, M., Roh, J.-H., Suzuki, H., Kumagai, H. \& Murooka, Y. (1994). Nucleotide sequence of the gene for monoamine oxidase (maoA) from Escherichia coli. J Ferm Bioeng 177, 315-319. 
Bradford, M. M. (1976). A rapid and sensitive method for the quantification of microgram quantities of protein utilizing the principle of protein-dye binding. Anal Biochem 72, 248-254.

Bruinenberg, P. G., Evers, M., Waterman, H. R., Kuipers, J., Arnberg, A. C. \& Ab, G. (1989). Cloning and sequencing of the peroxisomal amine oxidase gene from Hansenula polymorpha. Biochim Biophys Acta 1008, 157-167.

Cooper, R. A., Knowles, P. F., Brown, D. E., McGuirl, M. A. \& Dooley, D. M. (1992). Evidence for copper and 3,4,6-trihydroxyphenylalanine quinone cofactor in an amine oxidase from Gramnegative bacterium Escherichia coli K-12. Biochem J 288, 337-340.

Cuskey, S. M., Peccoraro, V. \& Olsen, R. H. (1987). Initial catabolism of aromatic biogenic amines by Pseudomonas aeruginosa PAO: pathway description, mapping of mutations, and cloning of essential genes. J Bacteriol 169, 2398-2404.

Durham, D. R. \& Perry, J. J. (1978). Amine dehydrogenase of Pseudomonas putida: properties of the heme-prosthetic group. J Bacteriol 135, 981-986.

Eady, R. R. \& Large, P. J. (1968). Purification and properties of an amine dehydrogenase from Pseudomonas AM1 and its role in growth on methylamine. Biochem J 106, 245-255.

Felsenfeld, G. (1960). The determination of cuprous ion in copper proteins. Arch Biochem Biophys 87, 247-251.

Frebort, I., Pavel, P., Luhova, L., Toyama, H., Matsushita, K., Hirota, S., Kitagawa, T., Ueno, T., Asano, Y., Kato, Y. \& Adachi, O. (1996). Two amine oxidases from Aspergillus niger AKU 3302 contain topaquinone as the cofactor: unusual cofactor link to the glutamyl residue occurs only at one of the enzymes. Biochim Biophys Acta 1295, 59-72.

Govindaraj, S., Eisenstein, E., Jones, L. H., Sanders-Loehr, J., Chistoserdov, A. Y., Davidson, V. L. \& Edwards, S. (1994). Aromatic amine dehydrogenase, a second tryptophan tryptophylquinone enzyme. J Bacteriol 176, 2922-2929.

Haywood, G. W. \& Large, P. J. (1981). Microbial oxidation of amines. Distribution, purification and properties of two primary amine oxidases from the yeast Candida boidinii grown on amines as sole nitrogen source. Biochem J 199, 187-201.

van lersel, J., Frank Jzn, J. \& Duine, J. A. (1985). Determination of absorption coefficients of purified proteins by conventional ultraviolet spectrophotometry and chromatography combined with multi wavelength detection. Anal Biochem 151, 196-204.

Janes, S. M., Mu, D., Wemmer, D., Smith, A. J., Kaur, S., Maltby, D., Burlingame, A. L. \& Klinman, J.P. (1990). A new redox cofactor in eukaryotic enzymes: 6-hydroxydopa at the active site of bovine serum amine oxidase. Science 248, 981-987.

Kitto, G. B. (1969). Intra- and extra-mitochondrial malate dehydrogenases from chicken and tuna heart. Methods Enzymol 13, 106-116.

Knowles, P. F. \& Dooley, D. M. (1994). Amine oxidases. In Metal Ions in Biological Systems vol. 30, pp. 361-403. Edited by H. Seigel. New York: Marcel Dekker.

Kumagai, H., Matsui, H., Ogata, K. \& Yamada, H. (1969). Properties of crystalline tyramine oxidase from Sarcina lutea. Biochim Biophys Acta 171, 1-8.

Large, P. J. \& Haywood, G. W. (1990). Amine oxidases from methylotrophic yeasts. Methods Enzymol 188, 427-435.

Levering, P. R., van Dijken, J. P., Veenhuis, M. \& Harder, W. (1981). Arthrobacter P1, a fast growing versatile methylotroph with amine oxidase as a key enzyme in the metabolism of methylated amines. Arch Microbiol 129, 72-80.

Matsuzaki, R., Fukui, T., Sato, H., Ozaki, Y. \& Tanizawa, K. (1994). Generation of the topaquinone cofactor in bacterial monoamine oxidase by cupric ion-dependent autoxidation of a specific tyrosyl residue. FEBS Lett 351, 360-364.

Matsuzaki, R., Suzuki, S., Yamaguchi, K., Fukui, T. \& Tanizawa, K. (1995). Spectroscopic studies on the mechanism of the topaquine generation in bacterial monoamine oxidase. Biochemistry 34, 4524-4530.

Mu, D., Janes, S. M., Smith, A. J., Brown, D. E., Dooley, D. M. \& Klinman, J. P. (1992). Tyrosine codon corresponds to topaquinone at the active site of copper amine oxidases. J Biol Chem 267, 7979-7982.

Mu, D., Medzihradszky, K. F., Adams, G. W., Mayer, P., Hines, W. M., Burlingame, A. L., Smith, A. J., Cai, D. \& Klinman, J. P. (1994). Primary structures for a mammalian cellular and serum copper amine oxidase. J Biol Chem 269, 9926-9932.

Okamura, O., Murooka, Y. \& Harada, T. (1976). Regulation of tyramine oxidase synthesis in Klebsiella aerogenes. J Bacteriol 127, 24-31.

Parrot, S., Jones, S. \& Cooper, R. A. (1987). 2-Phenylethylamine metabolism by Escherichia coli. J Gen Microbiol 133, 347-351.

Rassoulzadegan, M., Binetruy, B. \& Cuzin, F. (1982). High frequency of gene transfer after fusion between bacteria and eukaryotic cells. Nature 295, 257-259.

Roh, H. J., Suzuki, H., Azakami, H., Yamashita, M., Murooka, Y. \& Kumagai, H. (1994). Purification, characterisation and crystallisation of monoamine oxidase from Escherichia coli K-12. Biosci Biotechnol Biochem 58, 1652-1656.

Shimizu, E., Odawara, T., Tanizawa, K. \& Yorifuji, T. (1994). Histamine oxidase, a $\mathrm{Cu}^{2+}$-quinoprotein enzyme of Arthrobacter globiformis. Biosci Biotechnol Biochem 58, 2118-2120.

Steinebach, V., Groen, B. W., Wijmenga, S. S., Niessen, W. M. A., Jongejan, J. A. \& Duine, J. A. (1995). Identification of topaquinone, as illustrated for pig kidney diamine oxidase and Escherichia coli amine oxidase. Anal Biochem 230, 159-166.

Steinebach, V., Benen, J. A. E., Bader, R., Postma, P. W., de Vries, S. \& Duine, J. A. (1996). Cloning of the maoA gene that encodes aromatic amine oxidase of Escherichia coli W3350 and characterization of the overexpressed enzyme. Eur $J$ Biochem 237, $584-591$.

Sugino, H., Ishibashi, M. S., Yamashita, M. \& Murooka, Y. (1991). Gene cloning of the maoA gene and overproduction of a soluble monoamine oxidase from Klebsiella aerogenes. Appl Microbiol Biotechnol 35, 606-610.

Sugino, H., Sasaki, M., Azakami, H., Yamashita, M. \& Murooka, Y. (1992). A monoamine-regulated Klebsiella aerogenes operon containing the monoamine oxidase structural gene $(m a o A)$ and the maoC gene. J Bacteriol 174, 2485-2492.

Tanizawa, K., Matsuzaki, R., Shimizu, E., Yorifuji, T. \& Fukui, T. (1994). Cloning and sequencing of phenylethylamine oxidase from Arthrobacter globiformis and implication of Tyr-382 as the precursor to its covalently bound quinone cofactor. Biochem Biophys Res Commun 199, 1096-1102.

Tipping, A. J. \& McPherson, M. J. (1995). Cloning and molecular analysis of the pea seedling copper amine oxidase. J Biol Chem 270, 16939-16946.

Vishniac, W. \& Santer, M. (1957). The thiobacilli. Bacteriol Rev 21, 195-213.

Yamada, H. \& Adachi, O. (1971). Amine oxidase (Aspergillus niger). Methods Enzymol 188, 705-709.

Yamada, H., Adachi, O. \& Ogata, K. (1965). Amine oxidases of microorganisms. Part II. Purification and crystallization of amine oxidases of Aspergillus niger. Agric Biol Chem 29, 649-654. 
Yamashita, M., Sakaue, M., Iwata, N., Sugino, H. \& Murooka, Y. (1993). Purification and characterization of monoamine oxidase from Klebsiella aerogenes. J Ferm Bioeng 76(4), 289-295.

Zhang, X., Fuller, J.H. \& McIntire, W. S. (1993). Cloning, sequencing, expression, and regulation of the structural gene for the copper/topaquinone-containing methylamine oxidase from
Arthrobacter P1, a gram-positive facultative methylotroph. J Bacteriol 175, 5617-5627.

Received 29 July 1996; revised 22 September 1996; accepted 26 September 1996. 